\title{
Polychaetes from deep pelagic zone of the Mid-Atlantic ridge
}

\author{
A.E. Zhadan ${ }^{1}$, A.B. Tzetlin² \\ ${ }^{1}$ White Sea Biological station, Biological Faculty, Moscow State University, Moscow 119992, \\ Russia. \\ e-mail: azhadan@wsbs-msu.ru (corresponding author) \\ ${ }^{2}$ Department of Invertebrate Zoology, Biological Faculty, Moscow State University, Moscow \\ 119992, Russia. \\ e-mail:atzetlin@wsbs-msu.ru
}

ABSTRACT: Polychaetes from bathypelagic zone of the Mid-Atlantic ridge were studied using light and scanning electron microscopy. Descriptions of Yndolacia sp. (Yndolaciidae), Hesionidae gen.sp. larvae, Amphinomidae gen. sp. and Buskiella abyssorum (Flotidae) are given. Yndolacia sp. differs from previously described specimens (Støp-Bowitz, 1987; Buzhinskaja, 2004) by combination of characters such as simple (not ramified) nuchal organ, separated first and second segments, number of segments and chaetae, and relative length of tentacular cirri. Yndolacia sp. has an unusual type of axial proboscis with dorsal part much longer than ventral, with ciliar bundles and glands openings on the inner surface. Phylogenetic position of Yndolaciidae is discussed. Hesionidae gen.sp. larvae show a combination of well developed body with the segments number close to that of adults, larval prostomium with very early appendage rudiments, and well-developed prototroch. This morphology can be considered as an adaptation for prolonged swimming of a relatively large animal. Amphinomidae g. sp. These normally benthic animals were caught in the water column in spite of their adult morphology. They are most similar to Notopygos, but differ by absence of forked chaetae.

KEY WORDS: bathypelagic zone, Mid-Atlantic ridge, Polychaeta, Yndolacia, Hesionidae, Amphinomidae, Buskiella abyssorum.

\section{Полихеты из батипелагической зоны Срединно-Атлантического хребта}

\author{
А.Э. Жадан ${ }^{1}$, А.Б. Цетлин ${ }^{2}$ \\ ${ }^{1}$ Беломорская биологическая станщия им. Н.А. Периова биологического факультета МГУ \\ им. М.В.Ломоносова, Ленинские горы, Москва 119992 Россия. \\ e-mail:azhadan1@gmail.com \\ ${ }^{2}$ Кафедра зоологии беспозвоночных биологического факультета МГУ им. М.В.Ломоносова, \\ Ленинские горы, Москва 119992 Россия. \\ e-mail:atzetlin@gmail.com
}

РЕЗЮМЕ: С помощью световой и сканирующей электронной микроскопии были исследованы полихеты, собранные в толще воды над Срединно-Атлантическим 
хребтом. Дано описание Yndolacia sp. (Yndolaciidae), личинок Hesionidae gen.sp., Amphinomidae gen. sp. и Buskiella abyssorum (Flotidae). Yndolacia sp. отличается от ранее описанных экземпляров (Støp-Bowitz, 1987; Buzhinskaja, 2004) сочетанием следующих признаков: простыми, не разветвленными нухальными органами, разделенными первым и вторым сегментами, числом сегментов, числом щетинок в параподиях и относительной длиной щупальцевидных усиков. Yndolacia sp. имеет необычный тип аксиальной глотки, у которой спинная часть намного длиннее брюшной, с пучками ресничек и отверстиями желез на внутренней поверхности. Обсуждается положение индолациид в системе полихет. Личинки Hesionidae gen.sp. представляют собой комбинацию развитого тела с почти полным набором сегментов и личиночного простомиума с зачатками придатков и хорошо развитым прототрохом. Такое строение может рассматриваться как адаптация к долгому нахождению в планктоне относительно крупного животного. Взрослые представители типично донного семейства Amphinomidae были пойманы в толще воды. Эти животные больше всего похожи на представителей рода Notopygos, но отличаются отсутствием вилообразных щетинок.

КЛЮЧЕВЫЕ СЛОВА: батипелагическая зона, Срединно-Атлантический хребет, полихеты, Yndolacia, Hesionidae, Amphinomidae, Buskiella abyssorum.

\section{Introduction}

The polychaete fauna of the deep pelagic zone is still poorly explored. Every new portion of material or reinvestigation of old samples taken in the bathyal and abyssal depths gives new finding of enigmatic polychaetes like Flota, Poeobius or Yndolacia (Hartman, 1967; Buzhinskaja, 1977, 1996, 2006; Støp-Bowitz, 1987; Salazar-Vallejo, Zhadan, 2007; Osborn et al., 2007). This paper presents the results of an investigation of bathypelagic polychaetes from the Mid-Atlantic ridge with a description of rare and unusual findings.

\section{Material and methods}

Plankton samples were collected during 46th and 47th cruises of R/V "Academic Mstislav Keldysh" in 2001 and 2002 above hydrothermal vent fields of the Mid-Atlantic ridge with use plankton net BR 113/140 (opening $1 \mathrm{~m}^{2}$, mesh size $530 \mathrm{ìm}$ ), pinger "Benthos" was used during near bottom sampling. More detailed description of the sampling area is available in Vinogradov et al. (2003). Material was preserved with $4 \%$ formaldehyde solution. Ani- mals were examined with a stereomicroscope and OPTON MC 63s light compound microscope. Whole specimens or their body fragments were dried using the critical point method, coated with platinum-palladium and examined under a HITACHI 400A scanning electron microscope.

\section{Results}

Yndolacia $\mathrm{sp}$.

Figs 1-3.

Material examined. St. 4344, polygon TAG, $26^{\circ}$ $08.94^{\prime} \mathrm{N}, 44^{\circ} 47.36^{\prime} \mathrm{W}, 27.06 .02$, depth of sampling from $2980 \mathrm{~m}$, bottom depth $3000 \mathrm{~m}, 1$ poorly preserved specimen;- - St. 4409, polygon Rainbow, $36^{\circ} 15^{\prime} \mathrm{N}, 33^{\circ} 54^{\prime} \mathrm{W}$, depth of sampling $800-610 \mathrm{~m}$, bottom depth $2300 \mathrm{~m}, 1$ fragment without head; - St. 4301, polygon Bismark, $48^{\circ} 17^{\prime} \mathrm{N}, 16^{\circ} 10^{\prime} \mathrm{W}-48^{\circ} 18^{\prime} \mathrm{N}, 16^{\circ} 09^{\prime} \mathrm{W}, 1.06 .02$, depth of sampling 2300-1400 m, bottom depth $4800 \mathrm{~m}, 1$ specimen in good condition.

Description. Body flattened, tapering to posterior end (Fig. 1A). Length of the largest specimen including everted proboscis $4.9 \mathrm{~mm}$, maximal width at 3 rd chaetiger including parapodia $1.3 \mathrm{~mm}$. Bodies of the two complete specimens consist of 9 and 14 segments, fragment includes 7 segments.

Prostomium fused with peristomium ventrally; trapezium-shaped, anterior part wider than posterior; when proboscis is inverted, prostomium looks 


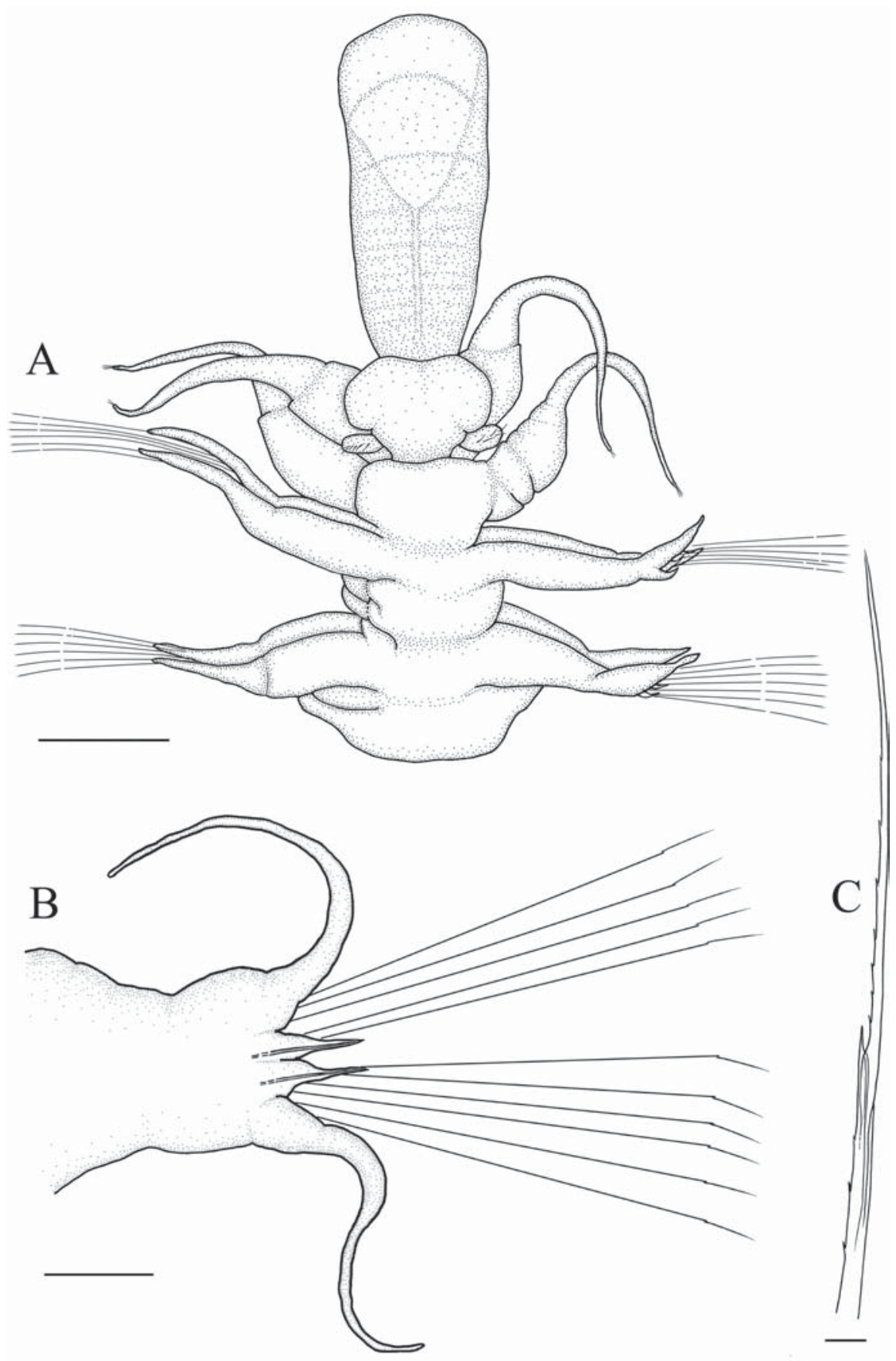

Fig. 1. Yndolacia sp.

A - anterior end, proboscis is everted, B - parapodium, C - chaeta. Scale bars: A $-250 \mu \mathrm{m}, \mathrm{B}-100 \mu \mathrm{m}, \mathrm{C}-$ $6 \mu \mathrm{m}$.

Рис. 1. Yndolacia sp.

A - передний конец, глотка вывернута, В - параподия, С - щетинка. Масштаб: А - 250 мкм, В - 100 мкм, С-6 мкм. 
bilobed (Fig. 2C). No visible appendages, except for two elongated processes with longitudinal ciliated stripes, presumably nuchal organs, on latero-posterior part of prostomium (Fig. 2C).

Axial muscular proboscis long, eversible, unarmed, without papillae, expanded distally; dorsal side much longer than ventral (like syringe needle) (Figs 1A, 2A, B, 3A),

Edge of the proboscis covered by short cilia, randomly distributed tufts of cilia form crescentshape field on inner surface of dorsal expansion of proboscis. Openings of gland cells with glands secret are visible (Fig. 3B).

First segment (peristomium) dorsally reduced and fused with prostomium. Each of two next anterior segments has pair of massive and long cirri with broad bases and abruptly narrowing distal parts. These cirri possess bundles of about 14 thin simple capillary chaetae, some of them slightly projected from distal end of cirri (Figs 2B, C, 3A). Next segments bear long and stout parapodia. Parapodia biramous, with long stem and equally-developed tapering podial lobes, each containing thin acicula. Dorsal and ventral cirri equal, long and curved (without any chaetae inside). Chaetae numerous, slightly serrated, long and thin, compound (Fig. 1Ñ $2 F, G)$. Pygidium with two broad triangle cirri. Very small oocytes (about $10 \mu \mathrm{m}$ in diameter) were observed in body cavity of all segments and parapodia in one specimen.

Discussion. Yndolacia lopadorrynchoides was described by Støp-Bowitz (1987) from the Gulf of Guinea and new family Yndolaciidae was erected for this monotypic genus. The next findings of Yndolaciidae were reported from the Arctic Ocean (Buzhinskaja, 2001) and from the Atlantic Ocean near Cape Verde Islands (Fernandes-Alamo et al., 2003) but without description of specimens. Later, Buzhinskaja (2004) reinvestigated the material from the Arctic Ocean refining of the diagnoses of the genus Yndolacia and described two new genera and two new species of Yndolaciidae, Y. polarsterni from the Laptev Sea and Paryndolacia tomopteroides from Canada Basin.

The specimens examined here are most similar to Yndolaciella polarsterni by having simple (not ramified) nuchal organ, separated first and second segments and the general shape of parapodia. They differ by the number of segments: 14 (while holotype of Yndolaciella polarsterni has 9) and numerous chaetae in parapodia (one to three in each ramus in the holotype). Besides, tentacular cirri in specimens described here are as long as body width, while in the Yndolaciella polarsterni holotype they are 7 times longer. All listed above characters are more peculiar for Yndolacia lopadorrhynchoides.

We suppose that the differences between $\mathrm{Yn}$ dolacia and Yndolaciella are related to the size variability and, probably, poor condition of most investigated specimens. Buzhinskaja (2004) considers small number of segments an apomorphic character for the genus Yndolaciella. Possibly Yndolaciella will become junior synonym of Yndolacia. Further studies are required to resolve this problem.

The taxonomic position of Yndolaciidae remains uncertain. Some characters, such as compound chaetae, aciculae in both rami of parapodia, dorsal and ventral cirri, and axial muscular proboscis suggest that it could be referred to Palpata Aciculata Phyllodocida. However, Yndolaciidae have neither antennae nor palps, and have several unique characters, such as the shape of the proboscis and tentacular cirri with bundles of chaetae. These cirri seem to be parapodial rudiments, such as demonstrated for Tomopteridae (Åkesson, 1962), rather than homologous with enlarged anterior cirri typical for other phyllodocids. Buzhinskaja (2004) proposed ancestral position of the family Yndolaciidae within Phyllodocida arguing this proposition by primitive and poorly developed nervous system and biramous parapodia with equal rami and similar cirri without cirrophores. She also considered absence of cephalic appendages of yndolaciids as ancestral state for Phyllodocidae. If one accepts this hypothesis, then independent origin of palps in Phyllodocida and other Palpata should be accepted. However, this assumption contradicts the data on homology of palps in many polychaete families based on study of nervous system (Orrhage, Müller, 2005). Buzhinskaja (2004) noted similarity of yndolaciids with tomopterids. Indeed, they share such characters as biramous parapodia with long podial stems and equal rami and tentacular cirri with inner chaeta. Probably Yndolaciidae are close to the ancestors of Tomopteridae that lost almost all chaetae.

The proboscis of Yndolaciidae differs from that of phyllodocids by its shape: it is not cylindrical, its dorsal part is much longer than ventral; its inner surface bears bundles of cilia and glands openings. The feeding method of yndolaciids is unclear. Both macrophagy and suspension feeding using cilia and mucus are possible.

\section{Hesionini indet. (larvae)}

Fig. 4A-H.

Material examined. St. 4149, polygon Bismark, $48^{\circ}$ $05^{\prime} \mathrm{N}, 16^{\circ} 10^{\prime} \mathrm{W}, 11.06 .2001$, depth of sampling $600-400$ $\mathrm{m}$, bottom depth $4700 \mathrm{~m}, 2$ specimens; St. 4423, polygon Bismark, $48^{\circ} 06^{\prime} \mathrm{N}, 16^{\circ} 08^{\prime} \mathrm{W}, 02.08 .2002$, depth of sampling 700-480 m, bottom depth $4800 \mathrm{~m}, 1$ specimen.

Description. Body short, includes 15 chaetigers. Length 1.5-2.5 mm, width without parapodia $430 \mu \mathrm{m}$. Prostomium short and very wide, with near straight anterior margin, bears rudiments of median and lateral antennae and palps. Median antenna 

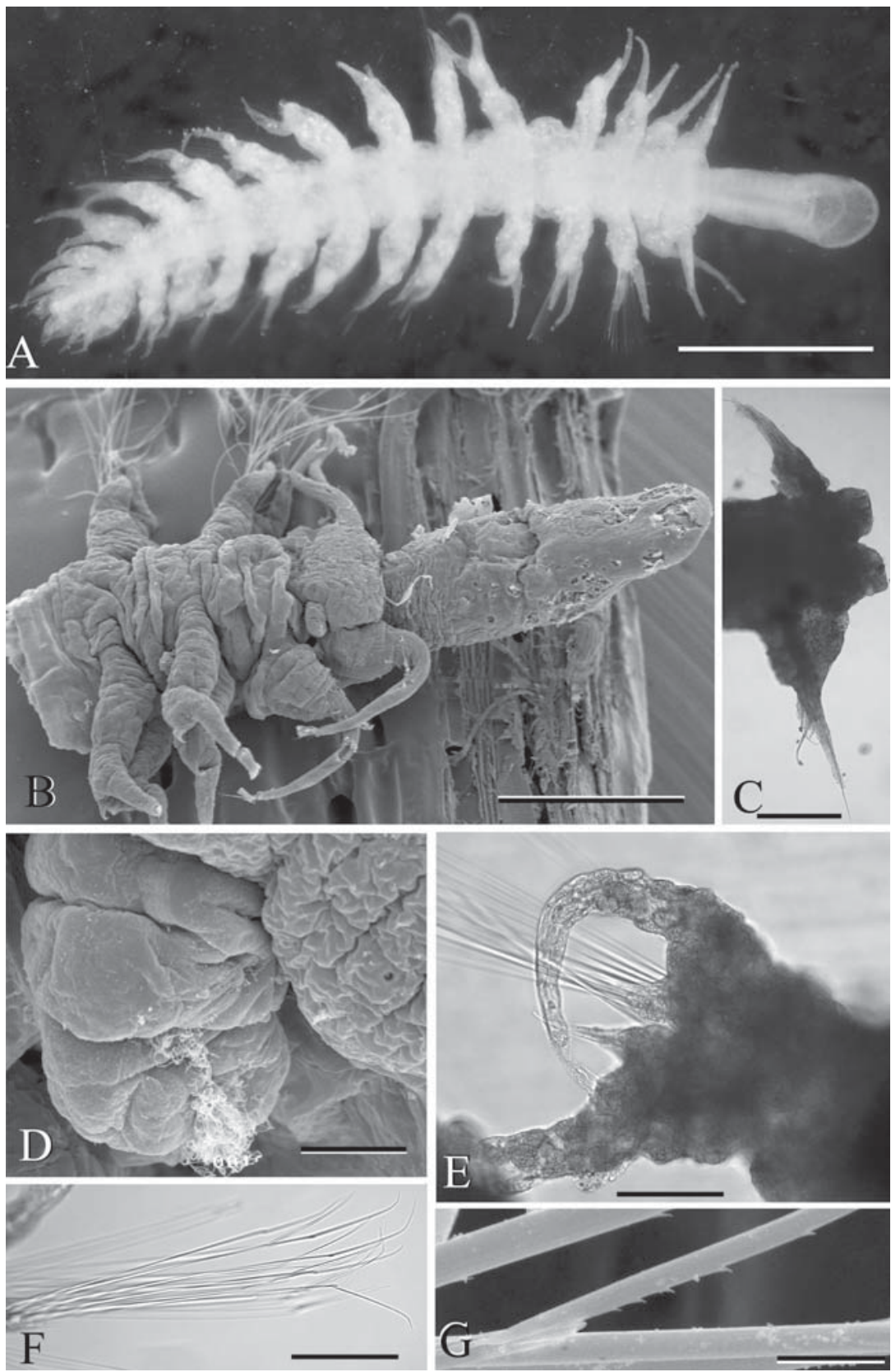

Fig. 2. Yndolacia sp.

A - whole animal with everted proboscis, dorsal view, B - anterior end, dorsal view, C - anterior end with inverted proboscis, dorsal view, D - nuchal organ (?), E - parapodia, F, G - chaetae. A, C, E, F - light microscopy; B, D, $\mathrm{G}-$ SEM. Scale bars: A $-750 \mu \mathrm{m}, \mathrm{B}-400 \mu \mathrm{m}, \mathrm{C}-200 \mu \mathrm{m}, \mathrm{D}-20 \mu \mathrm{m}, \mathrm{E}, \mathrm{F}-80 \mu \mathrm{m}, \mathrm{G}-8 \mu \mathrm{m}$.

Рис. 2. Yndolacia sp.

A — общий вид с вывернутой глоткой, вид со спины, В — передний конец, вид со спины, С — передний конец с ввернутой глоткой, вид со спины, D - нухальный орган (?), E - параподия, F, G - щетинки. А, C, E, F световая микроскопия; B, D, G - СЭМ. Масштаб: А - 750 мкм, В - 400 мкм, C - 200 мкм, D - 20 мкм, E, $\mathrm{F}-80$ мкм, $\mathrm{G}-8$ мкм. 


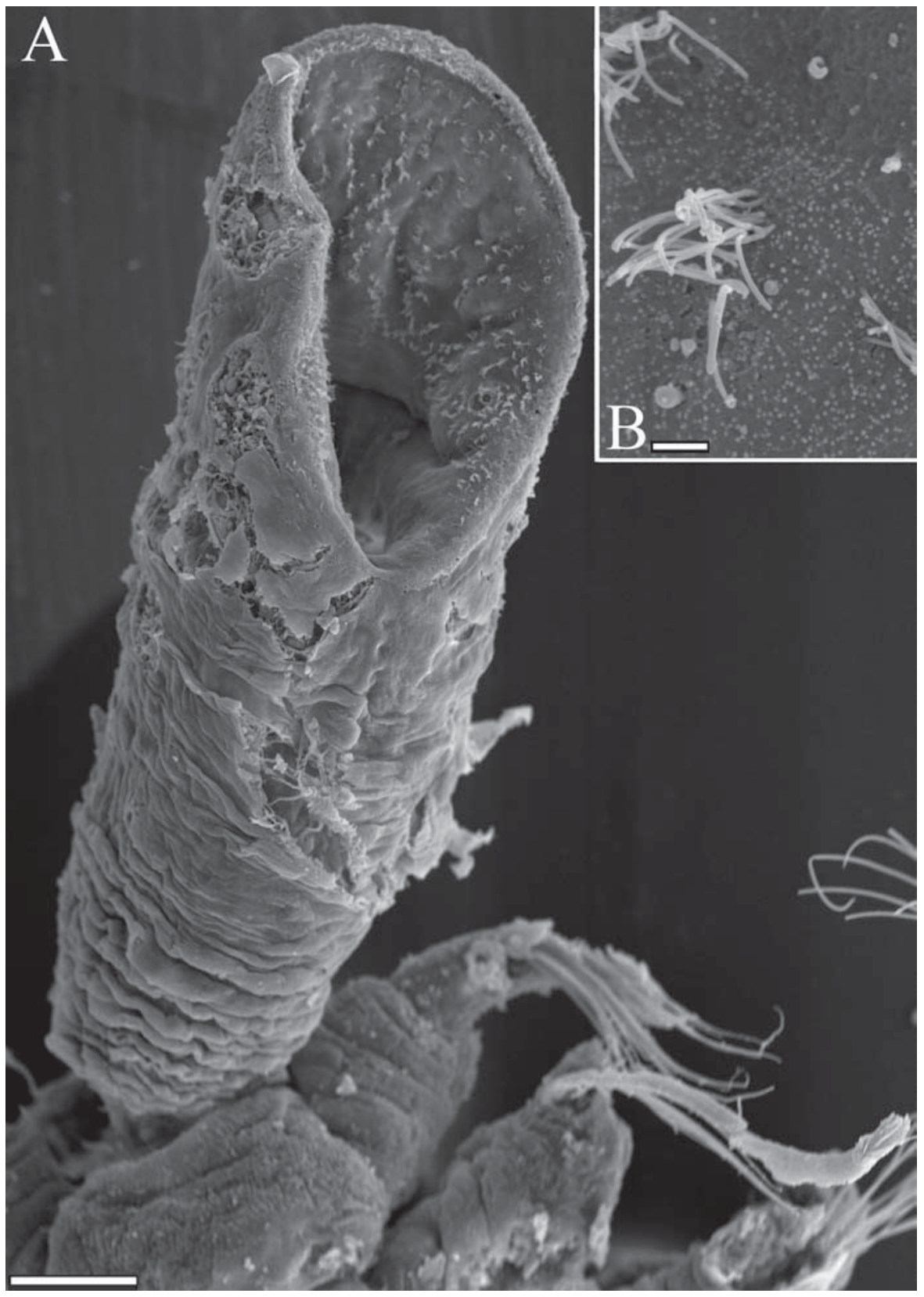

Fig. 3. Yndolacia sp.

A - anterior end with everted proboscis, ventro-lateral view, B - part of inner proboscis surface, ciliary bundles and glands secret are visible. Scale bars: A $-100 \mu \mathrm{m}, \mathrm{B}-100 \mu \mathrm{m}$.

Рис. 3. Yndolacia sp.

А - передний конец с вывернутой глоткой, вентро-латеральный вид, В - участок внутренней поверхности глотки, видны пучки ресничек и секрет желез. Масштаб: А - 100 мкм, В - 100 мкм. 

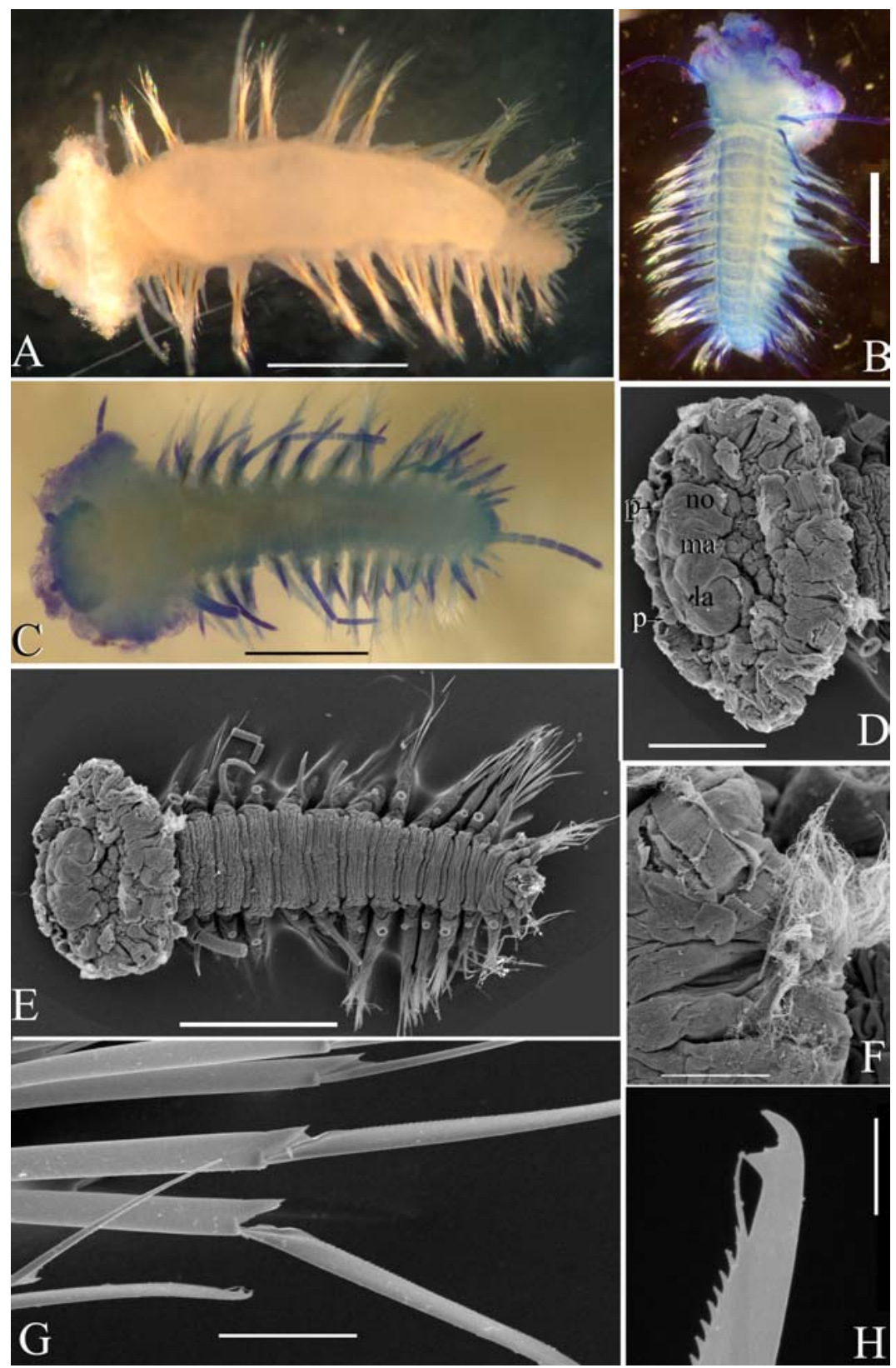

Fig. 4. Hesionidae gen. sp. larvae.

A-C, E - whole animal, A , C, E - dorsal view, B - ventral view, B and C stained with methylen blue, D - anterior end, $\mathrm{F}$ - section of collar with ciliation, $\mathrm{G}$ - chaetae, $\mathrm{H}$ - tip of chaeta. Abbreviations: la - lateral antenna, ma median antenna, no - nuchal organ, $\mathrm{p}-$ palps. A-C - light microscopy; D-H - SEM. Scale bars: A-C, E - 600 $\mu \mathrm{m}, \mathrm{D}-300 \mu \mathrm{m}, \mathrm{F}-80 \mu \mathrm{m}, \mathrm{G}-30 \mu \mathrm{m}, \mathrm{H}-4 \mu \mathrm{m}$.

Рис. 4. Hesionidae gen. sp. личинки.

A-C, Е- общий вид, А, C, Е-вид со спины, В - вид с брюшной стороны, В и С- окраска метиленовым синим, $\mathrm{D}$ - передний конец, $\mathrm{F}$ - участок ресничного воротничка, $\mathrm{G}$ - щетинки, $\mathrm{H}$ - кончик щетинки. la латеральная антенна, та - медиальная антенна, по - нухальный орган, $\mathrm{p}$ - пальпы. А-C - световая микроскопия; D-H - CЭМ. Масштаб: A-C, E - 600 мкм, D - 300 мкм, F - 80 мкм, G - 30 мкм, $\mathrm{H}-4$ мкм. 
posterior-dorsally inserted on prostomium. Two pairs of orange-brownish eyes situated in a transversal line across the prostomium; inner pair smaller than outer one. Nuchal organs are two separated ciliated bands on posterior part of prostomium. Very large (900 ìm in diameter) folded collar situated behind prostomium. Collar bears ciliated belt with cilia arranged in three rows (Fig. 4F). Cirrophores of anterior cirri not fused. Chaetae absent on segments 1-3. Dorsal cirri articulated, enlarged on segment 14. Three anterior pairs of ventral cirri differ from last by presence of large cirrophores. Parapodia uniramous, with a dark aciculae and a bundle of chaetae. Dorsal cirri long, with cirrophores and articulated cirrostyles that can be easily lost, ventral cirri short. Chaetae compound, blades serrated, distally bidentate. Pygidium with two cirri.

Discussion. A number of characters indicate that the larvae are members of Hesionini (sensu Pleijel, 1998) such as short and stout body shape, dark aciculae, and bidentate neurochaetae. Hesionini have chaetiger number fixed to 16 and segment number fixed to 21 , and specimens studied here have 15 chaetigers. However, we cannot place these larvae within any genus of Hesionini as many characters do not appear in their final condition until relatively late in the ontogeny (Rouse, Pleijel, 2001).

All hesionids are benthic animals, no holopelagic adults are described. There are no reports of juvenile Hesionini in the plankton. The adults of subfamily Ophioodrominae, Ophiodromus pugenensis Johnson and Gyptis brevipalpa HartmannSchröder swim during night time up to $2 \mathrm{~m}$ off the bottom in upper subtidal in the Gulf of California (Alldredge, King, 1985).

Larvae in our material represent a combination of quite developed adult body with almost adult segment number, enlarged anterior cirri with larval prostomium with very early rudiments of appendages. Large ciliated collar is not characteristic for hesionid larvae (Bhaud, 1971; Haaland, Schram, 1982, 1983; Pleijel, 1998). This collar is situated in front of the mouth, so it can be considered as an enlarged prototroch. Such a large prototroch may be an adaptation for prolonged swimming of a relatively big larva. Some similarity can be noted with larvae of Lopadorrhynchus (see Åkesson, 1967), pelagic larvae of Phyllodocidae described by Blake (1975) from the California, and unusual giant pelagic larvae of Phyllodocidae described by Tzetlin (1998) from the Indian Ocean. The latter consists of two distinct regions, a large spherical trochophore and a posterior long rudiment of the adult body. This pattern of development of the adult body may be adaptation for a long pelagic life and rapid settlement of the species that inhabits slopes of islands and seamounts located far apart.
In the absence of appropriate environmental cues larvae of benthic marine invertebrates may delay their metamorphosis (Pechenik, Cerulli, 1991). This phenomenon was reported in polychaete families Chaetopteridae, Spionidae, Terebellidae, Amphinomidae, Poecilichaetidae and Serpulidae (Bhaud et al., 1990; Qian, Pechenik, 1998). According to Bhaud et al. (1990) data extended planktonic life develops at two periods of the life cycle: 1) after larvae become competent to metamorphose while in the water column, and 2) when larvae arrive in the close proximity to the sediment. Delaying metamorphosis promotes placement of offspring into suitable habitats and likely increasing genetic exchange among populations but there are also some risks associated with it. For example, larvae can be removed far from suitable for settlement biotopes by currents, risk of planktonic predation increases with elongation of larval planktonic phase, delayed metamorphosis also can reduce juvenile fitness by reducing postmetamorphic survivorship or growth rate (Pechenik, Cerulli, 1991).

\section{Amphinomidae indet.}

Fig. 5A-J.

Material examined. St. 4406, polygon Rainbow, $36^{\circ} 14.85^{\prime} \mathrm{N}, 33^{\circ} 53.07^{\prime} \mathrm{W}, 21.07 .2002$, depth of sampling 2140-1646 m, bottom depth 2175 m, 1 specimen; St.4344, polygon $\mathrm{TAG}, 26^{\circ} 08.94^{\prime} \mathrm{N}, 44^{\circ} 47.36^{\prime} \mathrm{W}, 27.06 .2002$, depth of sampling $2800-2250 \mathrm{~m}$, bottom depth: $2850 \mathrm{~m}$, 1 specimen.

Description. Body short, tapering anteriorly and posteriorly, 10 chaetigers. Prostomium rounded with dorsal median antenna, dorsal pair of antennae and a ventral pair of palps. Posterior part of prostomium forms folded caruncle with ciliated bands reaching level of the fourth segment. One specimen has everted ventral pharynx. Its dorsal surface is ciliated and glandular, inner surface is folded, without cilia. The first segment bears noto- and neuropodia with reduced lobes and two pairs of long cirri. Parapodia biramous, with widely arranged rami, parapodial lobes small, poorly developed, bear dorsal but no ventral cirri. Segments VI-IX bear a pair of dichotomously branched gills. The most developed gills on 6-7 chaetigers. Pygidium round, without cirri. Chaetae simple, brittle, strongly serrated, of two types, a long and a short/broader bladed type. Ventral nerve cord and circum- oesophageal connectives visible from ventral side. In the bigger specimen small oocytes visible through body wall in all segments and parapodia.

Discussion. We refer these animals to the family Amphinomidae because they possess a typical for this taxon set of head appendages, caruncle, ventral pharynx, biramous parapodia, and branched gills. 

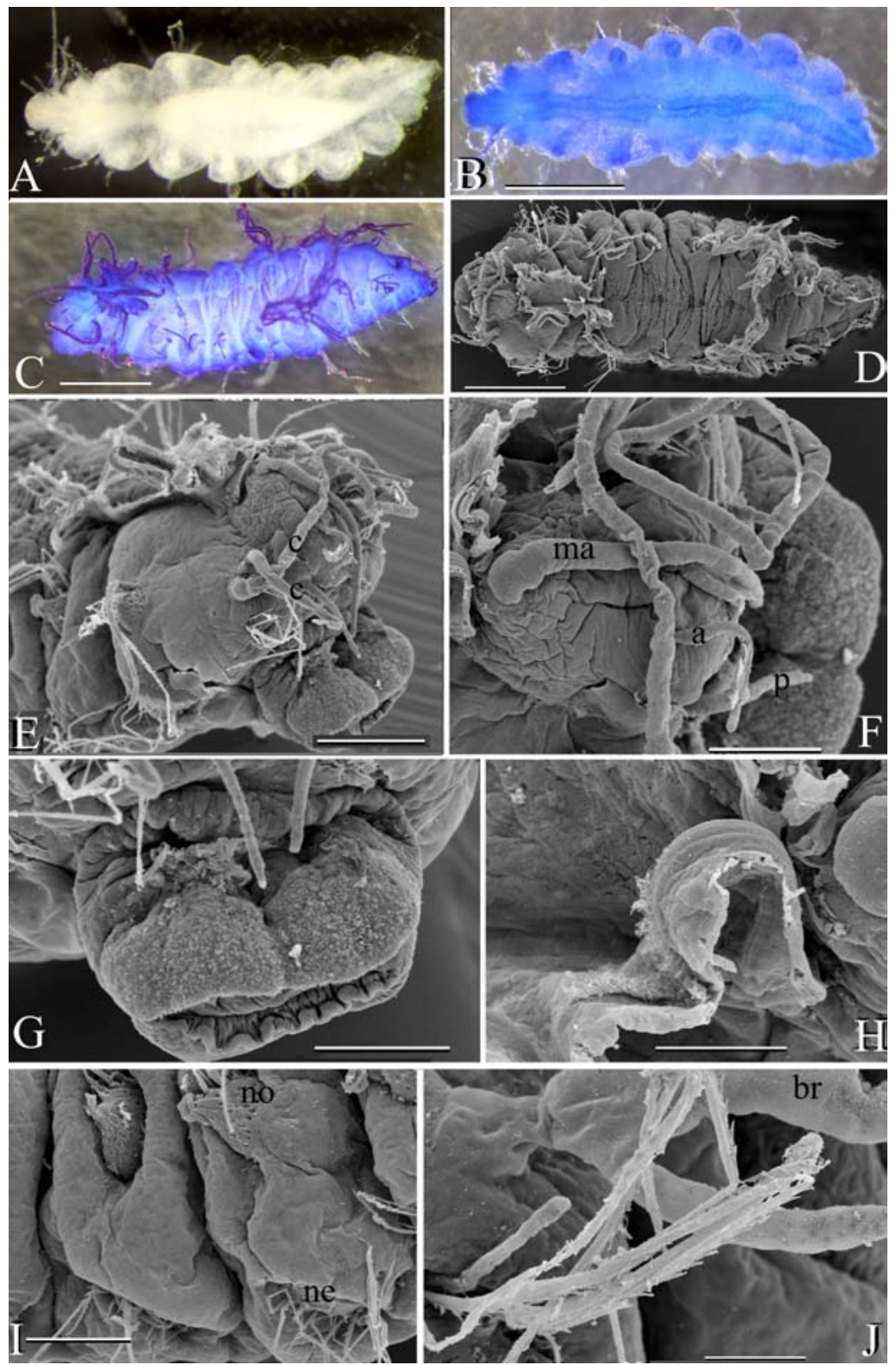

Fig. 5. Amphinomidae gen. sp.

A-D - whole animal, A, C, D - dorsal view, B - ventral view, the ventral nerve cord is visible, C - dorso-lateral view, E - anterior end with everted proboscis, lateral view, F - prostomium, G - pharynx, $\mathrm{H}$ - section of caruncle, I - parapodia of III and IV chaetigers, J - notopodium and branchium of VI chaetiger. Abbreviations: a - antenna, $\mathrm{c}$ - cirri, ma - median antenna, $\mathrm{p}$ - palp. A-C - light microscopy; D-J - SEM. Scale bars: A-D - $800 \mu \mathrm{m}, \mathrm{E}-$ $300 \mu \mathrm{m}, \mathrm{F}-150 \mu \mathrm{m}, \mathrm{G}, \mathrm{I}-200 \mu \mathrm{m}, \mathrm{H}, \mathrm{J}-80 \mu \mathrm{m}$.

Рис. 5. Amphinomidae gen. sp.

A-D - общий вид, A, C, D - вид со спины, В - вид с брюшной стороны, видна брюшная нервная цепочка, C — дорсо-латеральный вид, Е — передний конец с вывернутой глоткой, вид сбоку, F — простомиум, G — глотка, H - участок карункула, I - параподии III и IV сегментов, J - нотоподия и жабра VI сегмента. а — антенна, c - усик, та - медиальная антенна, p - пальпа. A-C - световая микроскопия; D-J - CЭМ. Масштаб: A-D 800 мкм, E - 300 мкм, F - 150 мкм, G, I - 200 мкм, H, J - 80 мкм. 
Probably our specimens belong to Notopygos Grube, 1855. The genus often has the folded caruncle and dendritically branched branchiae beginning half way down the body. But bifurcate chaetae characteristic for the genus were not found in our specimens.

Amphinomidae are mostly benthic animals, there are only few finding of amphinomids in the water column. One species - Hipponoe gaudichaudi Audouin et Milne-Edwards, 1830 was noted with association with pelagic goose barnacles (Cirripedia,Lepadomorpha) (Britayev, Memmy, 1989). Specimens of Pseudoeurythoe sp. swim during night time up to $2 \mathrm{~m}$ off the bottom in upper subtidal in the Gulf of California (Alldredge, King, 1985). At the same time the worms described here were collected 35 and $50 \mathrm{~m}$ above the bottom.

Amhinomids has very characteristic "rostraria" pelagic larva with two elongated feeding tentacles and bundles of very long larval chaetae (Mileikovsky, 1961; Bhaud et al., 1972). However, our specimens appear to be adults as they have a set of adult features, such as chaetae, branchiae, caruncle and head appendages, moreover, one specimen contains oocytes in the body cavity.

Many benthic animals, such as crustaceans, nematodes, plathelminthes, bivalves, gastropods, nemerteans and annelids can be found in water column. In river estuaries in Gulf of Maine 43 polychaetes species from 18 families was recorded during night sampling (Dean, 1978). Armonies (1994) studying drifting of benthic animals on tidal flats in the North Sea divided their migration in the water column into active and passive; he distinguished three types of active migrations differing by duration and distances. Individual escape is a reaction to a sudden threat such as a predator attack. Such migrations may have a time scale of seconds; they concern single individuals, and may be effective on a very small spatial scale. Group evasion of local subpopulations are reactions to the factors accumulating over some time and requiring a response in the near future to avoid environmental deterioration or resource depletion, either physical (e.g., oxygen, temperature, salinity) or biotic (e.g., overcrowding, interspecific competition). These migrations concern local groups of individuals on a time scale of hours to days and require a larger spatial scale in order to be effective. Finally, habitat changing of entire populations are prospective migrations that are not necessarily indicated by actual constraints, concerning populations or age groups. They occurs in temporal scales of hours to seasons, and in spatial scales of $\mathrm{cm}$ to $\mathrm{km}$. Examples range from the nocturnal emergence of benthic harpacticoid copepods for food uptake in the water column to seasonal changes of the occupied position in the tidal gradient in the polychaete Arenicola marina (L., 1758) or the bivalve Macoma balthica (L., 1758) and migrations for moulting, mating, or breeding (Armonies, 1994). Migration of benthic organisms into the water column probably promotes dispersal. Demersal behavior results in horizontal dispersal for many demersal zooplankton and some may actively search for potentially more favorable sites in which to re-enter the benthos (Alldredge, King, 1985). Most studies of migrations of benthic animals in the water column were performed in shallow-water habitats such as estuaries, tidal flats and coral reefs (Dean, 1978; Alldredge, King, 1985; Ohlhorsi, 1982; Armonies, 1994), while migrations of deep-water animals are still poorly known.

It is difficult to define the reason of occurrences of amphinomids described here in water column and the horizontal scale of their migration due to insufficient information we have. Most probably they do not spawn because swarming in the water column is not characteristic for the family and they do not have mature gametes in the body cavity. More likely they escape some environmental disturbance or migrate to water column for dispersion, but passive migration (for instance by currents) is also possible.

\section{Buskiella abyssorum}

Fig. 6A, B.

Material examined. St.4355, polygon Broken Spur, $29^{\circ} 10.67^{\prime} \mathrm{N}, 43^{\circ} 10.38^{\prime} \mathrm{W}, 25.06 .2002$, depth of sampling: $2960-650 \mathrm{~m}$, bottom depth: $3000 \mathrm{~m}, 1$ specimen.

Description. Body covered with transparent gelatinous sheath. Length $18 \mathrm{~mm}$, maximum width with sheath $4.2 \mathrm{~mm}$ (at level of the first chaetiger). Head partly inverted in the body. One pair of trifid organs; median branch twice as wide and long as the ones, lateral branches stemming from the ventral side of the base. Four anterior segments bear well developed parapodia, most chaetae broken. The first pair of parapodia enlarged and project anteriorly. Posterior part collapsed, parapodia not visible so number of segments unknown. Digestive system seen through the body wall; it contains big ventral pharynx, dark stomach and long thin intestine with small loop in anterior part. The ventral nerve cord has two well developed ganglia in each segment and about seven small thickenings between ganglia of adjacent segments.

Discussion. By the general body shape, gelatinous sheath, developed parapodia, and characteristic trifid organs the examined specimen is similar to Buskiella abyssorum McIntosh, 1885 described from the deep water of Sierra Leone. It differs by inverted head and by absence of chaetae which are lost in worm studied here. For a detailed description of the anterior end of this specimen studied by light microscopy and a discussion on homology of trifid organs see Salazar-Vallejo, Zhadan (2007). 

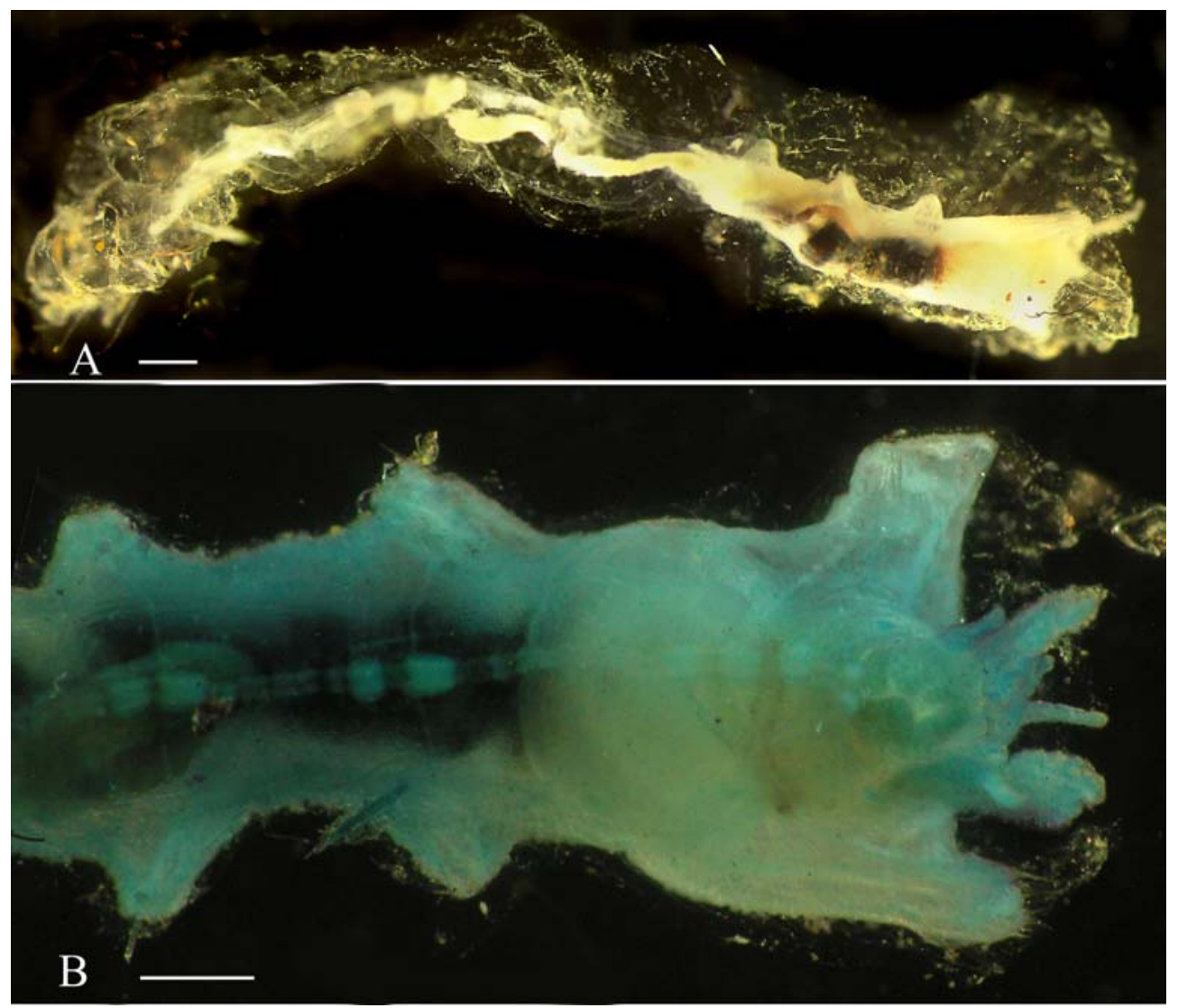

Fig. 6. Buskiella sp.

A - whole animal, B - anterior end. Scale bars: A -1 мм, B -0.5 мм.

Рис. 6. Buskiella sp.

A - общий вид, В - передний конец. Масштаб: A - 1 мм, В - 0,5 мм.

According to a recent revision (Salazar-Vallejo, Zhadan, 2007) two species of Flota (F. flabelligera Hartman, 1967 found offChile and $F$. vitjasi Buzhinskaja, 1977 from Kurile-Kamchatka Trench, Pacific Ocean) in fact belong to the genus Buskiella. B. abyssorum is the only species of the genus from the Atlantic Ocean. Both Pacific species differ from $B$. abyssorum by shorter and stouter body and by morphology of trifid organs. In B. flabelligera lateral branches are not longer than median one; in $B$. vitjasi lateral branches stemming from central one, besides, this species possess two groups of thin attached dorso-laterally tentacles with ciliated grooves (Hartman, 1967; Buzhinskaja, 1996). All these species share such synapomorphies as small and constant number of segments, trifid organs and ventral nerve cord with two ganglia in each segment, and multiple thickenings between ganglia of adjacent segments. These characters set them apart from Flabelligeridae within which Buskiella and Flota were initially placed. It was the reason why Buzhinskaja (1996) introduced a new family Flotidae. In cladistic analysis based on morphological data (Salazar-Vallejo et al., 2008) Flotidae is the sister group of Flabelligeridae; this clade was characterized by having chaetiger 2 shorter than proximal chaetigers, neurospines with entire tips, and pelagic life. At the same time analysis of molecular data shows that flotids are nested within Flabelligeridae (Osborn, Rouse, 2008). Phylogenetic relationships between flotids and Flabelligeridae need further study.

\section{Acknowledgments}

Authors are indebted to Georgy Vinogradov for providing the material and to Sergio SalazarVallejo and Brendan "Chip" Barret for helpful 
comments. This investigation was supported by Russian Foundation of Fundamental Researches; grant \# 03-04-48598, \# 07-04-00469, \# 0804-00512.

\section{References}

Alldredge A.L., King J.M. 1985. The distance demersal zooplankton migrate above the benthos: implications for predation // Marine Biology. Vol.84. P.253-260.

Armonies W. 1994. Drifting meio- and macrobenthic invertebrates on tidal flats in Königshafen: a review // Helgoländer Meeresuntersuchungen. Vol.48. P.299-320.

Bhaud M. 1972. Identification des larves d'Amphinomidae (Annelides polychetes) recueillies pres de Nosy-Be (Madagascar) et Problemes biologiques connexes // Cahiers ORSTOM (Office de la Recherche Scientifique et Technique Outre-Mer). Vol.10. P.203-216.

Bhaud M., Cazaux C., Mathivat-Lallier M.H. 1990. Metamorphose retardee chez les larves de polychetes et modele d'acquisition de la vie benthique // Oceanis. Vol.16. P.207-223.

Bhaud M.R. 1971. La phase larvaire d'Oxydromus propinquus (Marion et Bobretzky, 1875), Hesionidae // Vie et Milieu. Vol.22. P.153-162.

Blake J.A. 1975. The larval development of Polychaeta from the northern California coast. III. Eighteen species of Errantia // Ophelia. Vol.14. P.23-84.

Britayev T.A., Memmy M.P. 1989. Symbiotic association between the pelagic polychaete. Hipponoe gaudichaudi (Polychaeta, Amphinomidae) and goose barnacles (Cirripedia, Lepadomorpha) // Zoologicheski Zhurnal. Vol.68. P.30-35 [in Russian].

Buzhinskaja G.N. 2001. [The finding of pelagic polychaetes of the family Yndolaciidae Støp-Bowitz, 1987 in the Arctic Ocean. To the question on taxonomic status of the family] // Otchetnaya nauchnaya sessiya po itogam rabot 2000 g. Tezisy dokladov. 3-5 aprelya 2001. Rossiyskaya Akademia nauk, Zoologichesky Institut, St.Petersburg. P.13 [in Russian].

Buzhinskaja G.N. 1977. [Flota vitjasi sp. n. a new deepwater pelagic species of the family Fauveliopsidae (Polychaeta, Annelida)] // Issledovaniya fauny morei. Zoologicheskii Institut Akademii Nauk USSR. Vol.20. P.9-12 [in Russian].

Buzhinskaja G.N. 2004. Two new genera of the pelagic family Yndolaciidae (Polychaeta) from the Arctic Ocean with an addition to the description of Yndolacia lopadorrhynchoides Støp-Bowitz// Sarsia. Vol.89. P.338-345.

Buzhinskaja G.N. 2006. On the morphology of the genus FIola Hartman, 1967 and corroboration of the family status of Flotidae Buzhinskaja, 1996 (Polychaeta) // Zoosystematica Rossica. Vol.15. P.7-17.

Dean D. 1978. The swimming of bloodworms (Glycera spp.) at night, with comments on other species // Marine Biology. Vol.48. P.99-104.
Åkesson B. 1962. The embryology of Tomopteris helgolandica (Polychaeta) // Acta Zoologica Stokholm. Vol.44. P.135-199.

Akesson B. 1967. On the nervous system of the Lopadorhynchus larva (Polychaeta) // Arkiv för Zoologi. Vol.20. P.55-78.

Haaland B., Schram T.A. 1982. Larval development and metamorphosis of Gyptis rosea (Malm) (Hesionidae, Polychaeta) // Sarsia. Vol.67. P.107-118.

Haaland B., Schram T.A. 1983. Larval development and metamorphosis of Ophiodromusflexuosus (delle Chiaje) (Hesionidae, Polychaeta) // Sarsia. Vol.68. P. 85-96.

Hartman O. 1967. Polychaetous annelids collected by the USNS Eltanin and Staten Island cruises, chiefly from Antarctic Seas // Allan Hancock Monographs in Marine Biology. Vol.2. P.1-387.

Mileikovsky S.A. 1961. Assignment of two Rostrariatype polychaete larvae from the plankton of the northwest Atlantic to species Amphinome passasi Quatrefages 1865 and Chloenea atlantica McIntosh, 1885 (Polychaeta, Errantia, Amphinomorpha) // Doklady Akademii Nauk SSSR. Vol.141. P.754757 [in Russian].

Ohlhorsi S.L. 1982. Diel migration patterns of demersal reef zooplankton // Journal of Experimental Marine Biology and Ecology. Vol.60. P.1-15.

Orrhage L., Müller M.C.M. 2005. Morphology of the nervous system of Polychaeta (Annelida) // Hydrobiologia. Vol.535-536. P.79-111.

Osborn K. J., Rouse G.W., Goffredi S.K., Robison B.H. 2007. Description and relationships of Chaetopterus pugaporcinus, an unusual pelagic polychaete (Annelida, Chaetopteridae) // The Biological Bulletin. Vol.212. P.40-54.

Osborn K.J., Rouse G.W. 2008. Multiple origins of pelagicism within Flabelligeridae (Annelida) // Molecular Phylogenetics and Evolution. Vol.49. P.386-392.

Pechenik J.A., Cerulli T.R. 1991. Influence of delayed metamorphosis on survival, growth, and reproduction of the marine polychaete Capitella sp. // Journal of Experimental Marine Biology and Ecology. Vol.151. P.17-27.

Pleijel F. 1998. Phylogeny and classification of Hesionidae (Polychaeta) // Zoologica Scripta. Vol.27. P.89163.

Qian P-Y., Pechenik J.A. 1998. Effects of larval starvation and delayed metamorphosis on juvenile survival and growth of the tube-dwelling polychaete Hydroides elegans (Haswell) // Journal of Experimental Marine Biology and Ecology. Vol.227. P.169-185.

Rouse G.W., Pleijel F. 2001. Polychaetes. Oxford University Press. Pp.1-354.

Salazar-Vallejo S.I., Zhadan A.E. 2007. Revision of Buskiella McIntosh, 1885 (including Flota Hartman, 1967), and description of its trifid organ (Polychaeta, Flotidae) // Invertebrate Zoology. Vol.4. P.65-82.

Salazar-Vallejo S.I., Carrera-Parra L.F., Fauchald K. 2008. Phylogenetic affinities of the Flabelligeridae (Annel- 
ida, Polychaeta) // Journal of Zoological Systematics and Evolutionary Research.Vol.46. P.203-215.

Støp-Bowitz C. 1987. A new genus and species (Yndolacia lopadorrhynchoides) of pelagic polychaetes representative of a new family, Yndolaciidae // Bulletin of the Biological Society of Washington. Vol.7. P.128-130.
Tzetlin A.B. 1998. Giant pelagic larvae of Phyllodocidae (Polychaeta, Annelida) // Journal of Morphology. Vol. 238. P.93-107.

Vinogradov G.M., Vereshchaka A.L., Aleynik D.L. 2003. [Distribution of the zooplankton above hydrothermal vent fields of the Mid-Atlantic ridge] // Oceanologia. Vol.43. P.696-709 [in Russian]. 